\title{
Composition of Solid Waste in Al Jabal AI Akhdar, a Mountain Region Undergoing Rapid Urbanization in Northern Oman
}

\author{
Abdullah I. Al-Mahrouqi and Reginald Victor*
}

Department of Biology, College of Science, Sultan Qaboos University, P.O. Box: 36, PC 123, AlKhoud, Muscat, Sultanate of Oman. *Email: rvictor@squ.edu.om.

\begin{abstract}
There is a lack of data on the generation and composition of waste in rural areas worldwide. The present study analyzed the composition of solid waste in Al Jabal Al Akhdar, a rural mountain region in the Sultanate of Oman, which is presently experiencing a rapid rate of urbanization due to tourism development. The solid wastes here are generated by the municipality collecting waste from residential, commercial, institutional and recreational areas, the military from a training camp and a few non-governmental private companies from their camps and hotels. The whole load from each of the three sources was manually segregated each month from June 2013 - May 2014 . The results indicated that plastic is the dominant category in the wastes collected by the municipality and accounts for $26.7 \%$, followed by paper $(17.9 \%)$ and then food $(14.4 \%)$. Food is the dominant category in the wastes collected by the military and private companies and accounts for $36.5 \%$ and $45.5 \%$ respectively. Management issues associated with solid waste are briefly considered. The study concluded that the municipality should implement an improved system for the collection of plastic waste and initiate a system for recycling it; the military and private companies should reduce the quantities of food waste by improved planning and management of the catering services.
\end{abstract}

Keywords: Solid waste; Rural areas; Al Jabal Al Akhdar; Oman; Statistical analysis; Composition.
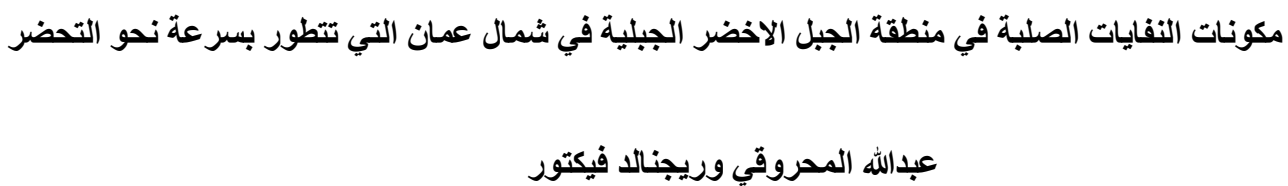

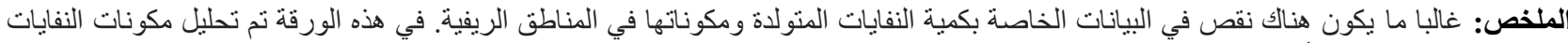

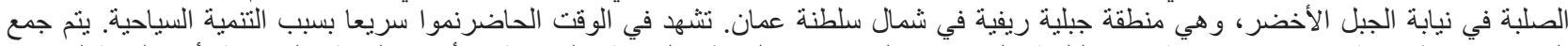

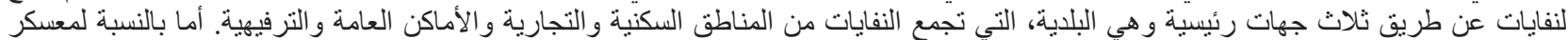

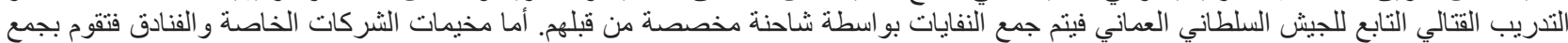

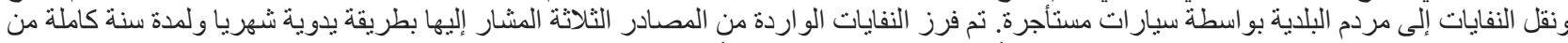

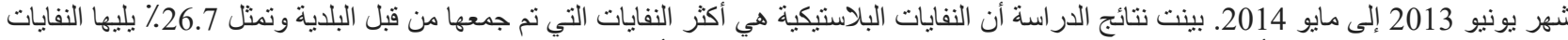

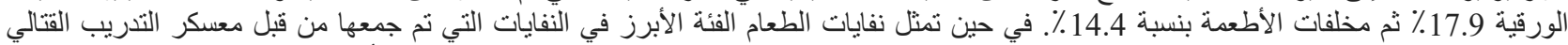

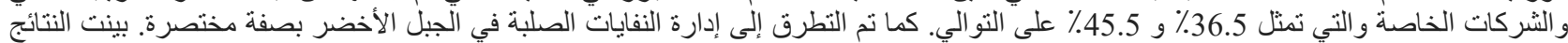

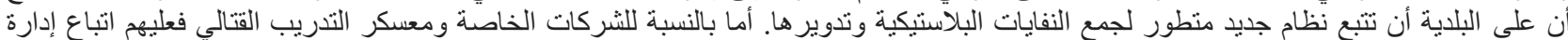
متطورة في التخلص من مخلفات الأطعمة. الكلمات المفتاحية: النفايات الصلبة، المناطق الريفية، الجبل الأخضر، عمان ، التحليل الإحصائي و المكونات.

\section{Introduction}

$\mathbf{T}$ he amount of solid waste generated throughout the world is increasing dramatically and continues to be a major problem in most of the developing countries affecting the environment, human and other organisms [1]. Waste composition differs from one place to another even in the same country or same district or sub-district [2]. It is influenced by many factors such as the income of the people, economic development, eating habits and consumption patterns [3].

Al Jabal Al Akhdar of the western Hajar Mountains is rapidly developing as a popular tourist destination in Oman. This area had restricted access until about two decades ago and was populated by remote rural communities. In 1993, the number of households in the area was 547 and the population was about 5227 people. Al Jabal Al Akhdar 


\section{ABDULLAH I. AL-MAHROUQI and REGINALD VICTOR}

branch of the Nizwa Municipality was responsible for the solid waste management and even donkeys were used to transport solid waste from remote areas. The infrastructure available for managing solid waste at that time was considered adequate. From 1995, the area opened up for urban development and the promotion of tourism. By 2010 , the number of households had increased to 803 with 8000 people. The projected estimate for 2016 at the same conservative rate of increase is over 1000 households and about 10000 people excluding the transient population of military personnel and tourists. The associated increase in the solid waste, as evidenced by observation, has not been subjected to any scientific study.

Open dumps are the most common waste disposal systems in Oman. These dumps, particularly if uncontrolled, are associated with human and environmental hazards due to foul odor, loss of amenity value, toxic leachate and contamination of drinking water sources [4]. Leachate is a liquid associated mainly with open dumps and it is produced when rainwater percolates through waste dumped in a disposal site [5]. Sources such as electronic goods, electroplating waste, paint waste, used batteries, ceramics, newspapers, motor oils, plastics, etc., when dumped with municipal solid waste increase the heavy metal concentrations in dumpsites [6].

Al Jabal Al Akhdar has one small open dump that receives all solid waste except the construction and demolition waste. To our knowledge there is no study on the qualitative and quantitative composition of the waste generated in this area. For the efficient management of solid waste including strategies for recycling and disposal, this information is needed [3], and therefore this study investigates the composition of solid waste as the first step toward integrated solid waste management.

\section{Study Area}

The study area, Al Jabal Al Akhdar (Figures 1a and b) which is the largest structural domain in the western Hajar mountain range, is located in Al Dakhliah Governorate of the Sultanate of Oman between latitudes $16^{\circ} 39^{\prime}$ and $26^{\circ} 30^{\prime}$ $\mathrm{N}$ and longitudes $52^{\circ} 00^{\prime}$ and $59^{\circ} 30^{\prime} \mathrm{E}$. It is $150 \mathrm{~km}$ southwest of Muscat and has a total land area of $26 \mathrm{sq}$. km. It is around 2000 - $3000 \mathrm{~m}$ above sea level (masl).

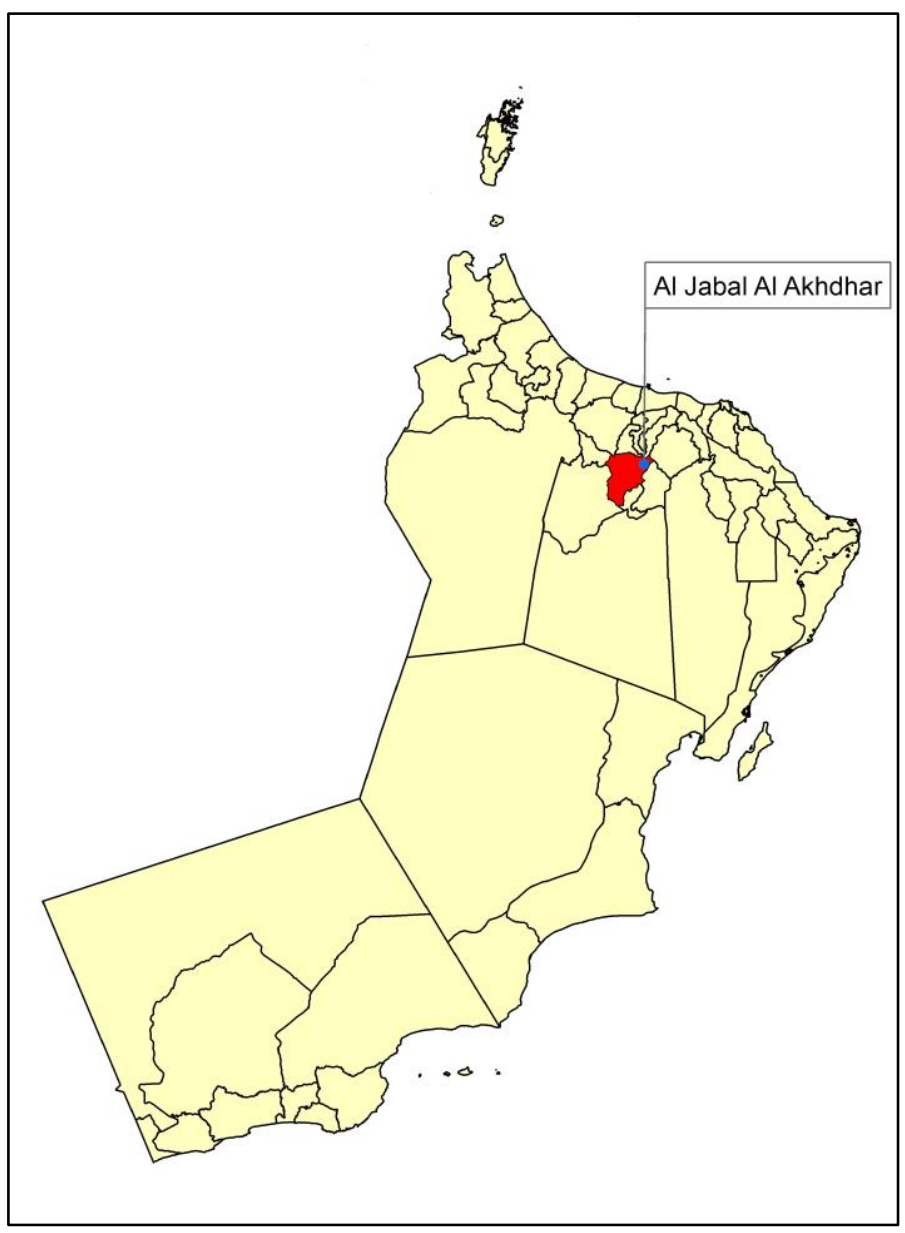

Figure 1a. The location of the Al Jabal Al Akhdar region in Oman. (Source: Oman Environmental Services Holding Company; Be'ah). 


\section{COMPOSITION OF SOLID WASTE}

The geology of Al Jabal Al Akhdar is unique and all rock groups found in the Oman Mountains are represented. The detailed geology of these mountains is given by Glennie [7] and Hanna [8]. The dump site is located on the Triassic Mahil formation of around $600 \mathrm{~m}$ in thickness. The formation is composed mainly of thick alternations of pinkish and yellowish dolomite rocks characterized by high permeability. Beds in the area are steeply dipping eastward toward the Izki area [8].

Al Jabal Al Akhdar (Figure 1a) is moderately cool in summer $\left(20-25{ }^{\circ} \mathrm{C}\right)$ and very cold in winter $\left(<0-10{ }^{\circ} \mathrm{C}\right)$. When the average summer temperature in Nizwa (500 masl) is $49{ }^{\circ} \mathrm{C}$, in Saiq, the main village on the plateau (20003000 masl) temperature averages around $25^{\circ} \mathrm{C}$ [9]. The annual rainfall occurs normally between June and August in summer and between December and January in winter although this varies from one place to another. The annual precipitation ranged from 115-413 $\mathrm{mm}$ for the period of 2000-2009 [9].

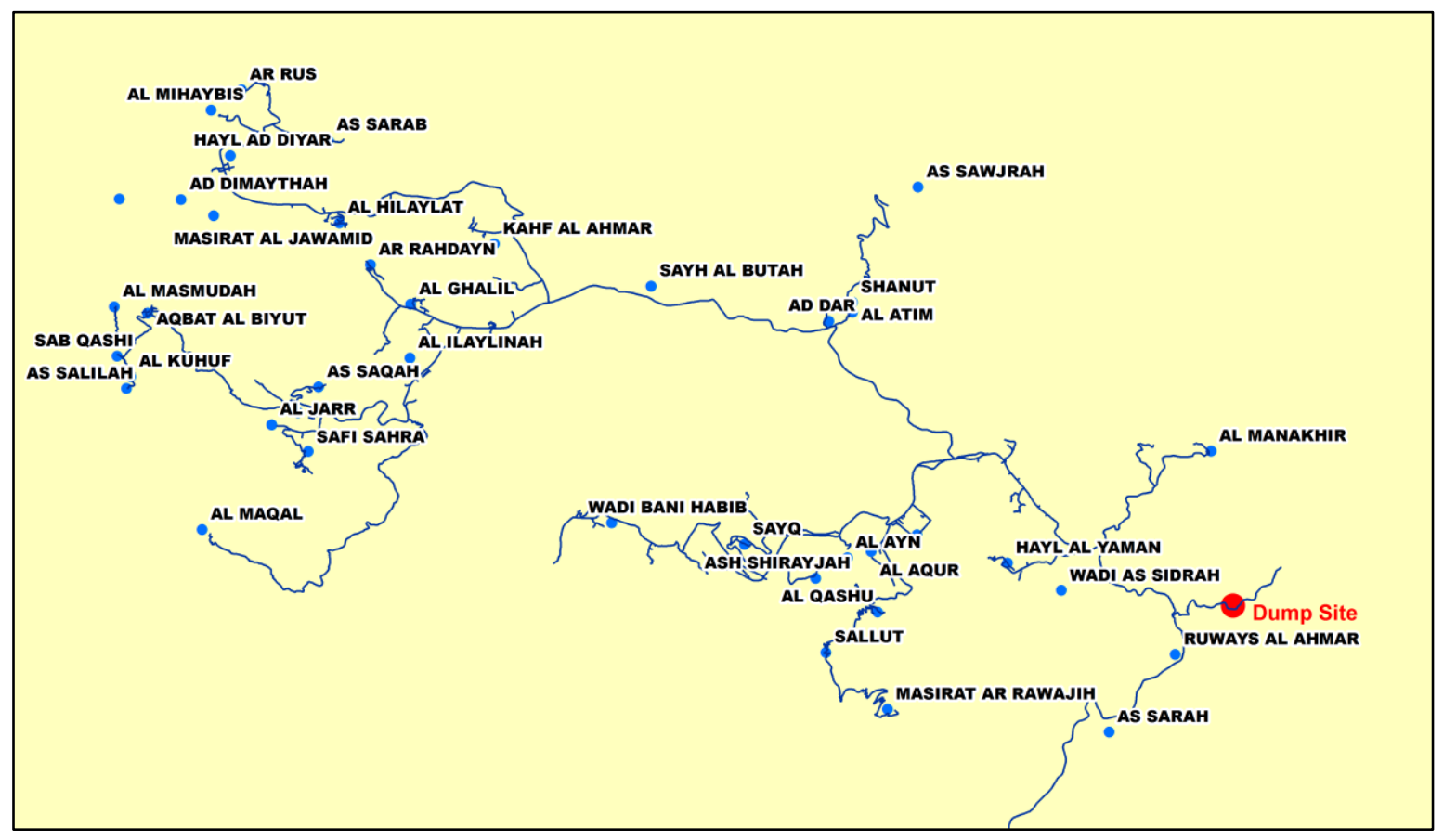

Figure 1b. Main villages in Al Jabal Al Akhdar (Source: Oman Environmental Services Holding Company; Be'ah).

Al Jabal Al Akhdar supports 48 small villages (Figure 1b). Agricultural farming inclusive of raising livestock is the most important activity of the local residents, and employ about one quarter of the population. Pomegranate, apricot, fig, grape, walnut, apple, plum, pear and peach are the most cultivated crops. Many animal fodders such as corn, oats and alfalfa are also cultivated. Most families raise livestock in private fens attached to their homes, particularly goats and sheep for food, the sale of wool and to provide fecal matter as a source of fertilizer for the crop production. Some villages produce rosewater in late spring of each year when the Damascus Rose (Rosa damascena) is in bloom.

Because of the intensive urban development in recent times, there has been a steady increase in the number of residents in certain parts of the Jabal. Many citizens who were originally from Al Jabal Al Akhdar but had become residents in the lower plains are returning to be a part of this urban development. Tourists and locals visit $\mathrm{Al} \mathrm{Jabal} \mathrm{Al}$ Akhdar to experience the cool weather, to camp, for landscape photography and to visit farming areas and traditional villages. The number of hotels has increased from one in 2006 to four in 2014, and another large hotel which belongs to the Ministry of Defense is still under construction. In addition, there are other apartments and rest-houses and some organizations such as the municipality have their own accommodation for their staff. The number of tourists has increased from 85,000 in 2006 to 134,000 in 2013[10]. The majority of the inhabitants are concentrated in Saih Katanah representing $26 \%$ of the population, and the rest are distributed in other villages. The population growth rate of Al Jabal Al Akhdar is 3.5\% per year [11].

The only open dumpsite in Al Jabal Al Akhdar has an area of $6223 \mathrm{~m}^{2}$. It is under the ownership of Nizwa Municipality. The method used to dispose of the waste is burning in order to reduce the volume because the area is small. The ash, with other unburnt waste, is transferred once annually to another site at a distance of $500 \mathrm{~m}$. Different wastes are not sorted, and at times, special wastes (clinical, industrial, and electronic) are also deposited in the municipal dump.

The dumpsite is located on a dry river bed from where waste can be washed away during rains and flash floods. The dump has no engineered measures for waste processing. It is not fenced off properly and has no leachate management or plans for landfill gas management or liners. Similarly, there are no operational measures, such as registration of users, control of the number of loads, or compaction of waste. 


\section{ABDULLAH I. AL-MAHROUQI and REGINALD VICTOR}

\section{Materials and Methods}

There are three different stakeholders for carrying solid waste to the dumpsite. The main collector is Nizwa Municipality (Al Jabal Al Akhdar Branch) which collects the waste from residential, commercial, institutional and recreational areas. They use either mini trucks $\left(2-3 \mathrm{~m}^{3}\right)$ or tippers $\left(18 \mathrm{~m}^{3}\right)$. The military bring their waste by their own compactor truck $\left(9 \mathrm{~m}^{3}\right)$. Normally they bring only one load daily except when they have special occasions. The third class of collector is non-governmental companies, which collect the waste from other private organization's camps and hotels. They use mini-trucks or pickups $\left(2-3 \mathrm{~m}^{3}\right)$. These three sources of waste were kept separate for assessing the composition.

The sampling program was carried out for one year at monthly intervals from June 2013 to May 2014. Klee [12] recommended that the solid waste sample should not be small, not less than $91 \mathrm{~kg}$ in order to avoid the high variance of the waste composition. Therefore, the whole loads of three different trucks, one from each source were sorted. The minimum weight for loads sorted from the municipality was $215 \mathrm{~kg}$ in June 2013 and the maximum weight was 998.5 $\mathrm{kg}$ in August 2013. The minimum weight for loads sorted from the military was $312 \mathrm{~kg}$ in June 2013 and the maximum weight was $779 \mathrm{~kg}$ in April 2014. The minimum weight for loads sorted from private companies was $213 \mathrm{~kg}$ in February 2014 and the maximum weight was $1028 \mathrm{~kg}$ in July 2013.

Each load was spread flat on a plastic sheet on the ground and was sorted manually by 10 laborers into 10 different components: paper/paperboards, plastics, food, textiles, leather/ rubber, metals, glass, wood, yard trimming and other (includes electrical/ electronic apparatus, nappies/sanitary products, paint waste, used batteries, ceramics, dead animals, used tires and other inert materials). Standard personal safety procedures such as gloves, masks, aprons and safety boots were used during the segregation process.

Each component was weighed using a balance with a $1000 \mathrm{~kg}$ scale and the weights were recorded. The percentage composition of each component was calculated. All percentages were arcsin transformed before analysis and normal distribution assumption was verified. The whiskers on bar graphs represent standard error (SE). After considering various models of ANOVA, the Analysis of Variance (ANOVA) completely randomized design was selected as the best to fit the experimental design used in this study. If there were significant differences among sources and components, the Tukey test was used as a post-hoc comparison to detect the location of significant differences. Comparisons of solid waste composition with those of previous studies, where possible, were performed using one sample t-tests with a non-zero $\mu$. All analyses were performed using EXCEL and PAST running on a Windows platform.

\section{Results and Discussion}

All solid waste collected in Al Jabal Al Akhdar, except for the construction and demolition waste, is sent to the municipal dumpsite; the latter is used as landfill for natural depressions and is not included in this study.

The solid wastes received by the dumpsite were analyzed under three separate waste streams; municipal, military and from private companies. The composition of the waste in each stream needs to be known to determine possible improvements that can be recommended specifically to the stakeholder who is responsible for that waste stream (e.g. the military). While some studies use categories such as recyclables, organics etc., to classify waste [13, 14], ten basic, descriptive categories were used here. This simple classification is easily understood by all stakeholders from uneducated lay people to those with advanced technical knowledge. Assessing the percentage of recyclables or organic material for example, could be easily determined from these categories.

From municipality records and personal observation of the loads of waste being delivered to the dumpsite, it is estimated that about 2560 tons are being generated annually in Al Jabal Al Akhdar. The estimated quantity of waste generated was calculated for each source from the number of trucks entering the dumpsite and the weight of the sampled loads. The estimated annual contribution of waste collected by the municipality was around $76.8 \%$ and the remaining waste was from the military (7.4\%) and private companies (15.8\%). Table 1 shows the composition of solid waste from the three sources in Al Jabal Al Akhdar for the period June 2013 - May 2014; the total weights of the 12 samples taken within each category are given.

The three main categories of waste received from the municipality were plastic (26.7\%), food (14.4\%) and paper $(17.9 \%)$ which represent $60 \%$ of the total waste. The ANOVA showed that there were significant differences (Figure 2a) among the mean percentages of the 10 categories $\left(F_{0.05,9,110}=1.97 ; p<0.05\right)$. Post-hoc comparisons using the Tukey test showed that food and paper were not significantly different from each other $(\mathrm{p}>0.05)$, while plastic was significantly higher than all other categories $(\mathrm{p}<0.05)$. These three main categories were significantly different from the other seven categories $(\mathrm{p}<0.05)$. The seven minor categories $(5-7 \%$ of the composition) were not significantly different from each other $(\mathrm{p}>0.05)$. 
Table 1. Total sample weights by category from the three sources for the period from June 2013 to May 2014. The values in the parentheses are percentages.

\begin{tabular}{llll}
\hline Total Weight of All Samples $(\mathbf{k g})$ & Municipality & Military & Private Companies \\
\hline Paper & $320(17.87)$ & $257(14.97)$ & $217(14.09)$ \\
\hline Food & $258(14.41)$ & $627(36.48)$ & $701(45.45)$ \\
\hline Plastic & $478(26.69)$ & $229(30.35)$ & $236(15.31)$ \\
\hline Metal & $104(5.81)$ & $139(8.06)$ & $110(7.71)$ \\
\hline Glass & $117(6.53)$ & $75(4.38)$ & $106(6.87)$ \\
\hline Textiles & $116(6.48)$ & $47(2.72)$ & $27(1.66)$ \\
\hline Wood & $94(5.25)$ & $103(5.99)$ & $62(4.04)$ \\
\hline Yard Trimming & $87(4.86)$ & $124(7.26)$ & $0(0)$ \\
\hline Rubber \& Leather & $90(5.03)$ & $62(3.59)$ & $40(2.59)$ \\
\hline Others & $127(7.09)$ & $55(3.20)$ & $44(2.83)$ \\
\hline Total & $1,791(100)$ & $1,718(100)$ & $1,543.5(100)$ \\
\hline
\end{tabular}

All the categories of municipal solid waste were generated primarily by households, as is similar to municipal waste generated elsewhere $[15,16]$. The mean percentage of food waste $(14.4 \%)$ was significantly higher $(\mathrm{p}<0.04)$ compared to the urban samples taken by the operator of Al Multaqa Landfill, Muscat in 2012 and 2013 (9.8\%) [17]. The actual food waste in Al Jabal Al Akhdar is likely to be higher than the 14.4\% reported in this study. This may be due to the fact that local residents feed their food wastes to domestic animals and discard only the surplus. In addition, cats, dogs and feral donkeys scavenge for food from the collection bins and only the remaining food waste is taken to the dumpsite.

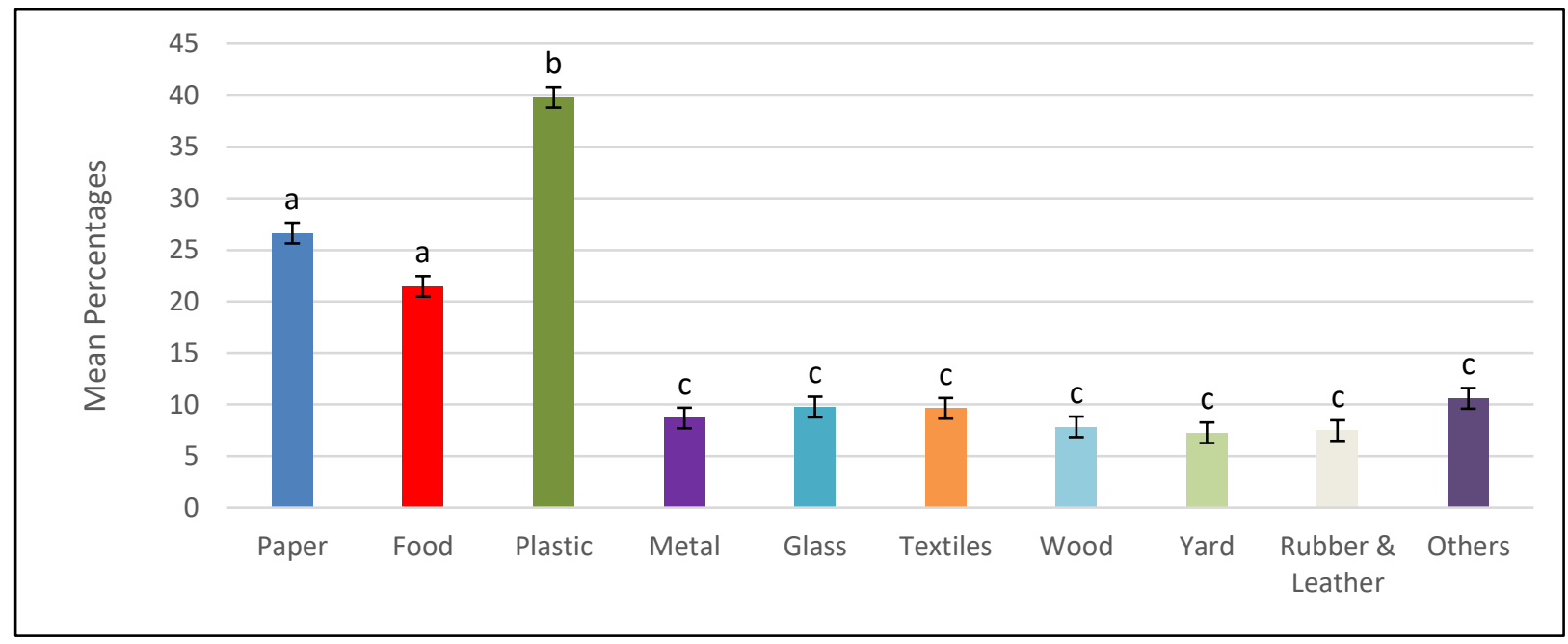

Figure 2a. Percentages of different categories of municipal waste generated. The bars labeled with the same letters are not significantly different from each other (Tukey test, $\mathrm{p}>0.05$ ).

A recent study in Muscat, Oman showed that food represented $28.2 \%$ of the municipal waste [18]. For a city generating 750 tons of municipal waste per day, this seems to be an overestimate. The sample size used by these investigators was very small ( $5 \mathrm{~kg}$ of a random sample of $20 \mathrm{~kg}$ ) in relation to the total amount of waste dumped. AbdAlqader and Hamed [19] stated that in order to study the composition, the minimum weight of the solid waste samples should not be less than $91 \mathrm{~kg}$. Small sample sizes are likely to provide inaccurate results. Other researchers indicated that the samples of solid waste should range between 50-136 kg [20]. According to another study conducted in different districts of Muscat Governorate, Oman in 1998 [21], the food wastes accounted for 38.8\% based on a total of 10 samples of $800-850 \mathrm{~kg}$ taken from five dumpsites. This estimate also may not be very accurate as there were relatively low numbers of samples.

The mean percentage of plastic waste (26.7\%) was higher than that (8.5\% and $17.2 \%)$ reported by El Zawahry et al. [21] and Palanivel and Sulaiman [18] respectively in Muscat. However, it is not significantly different from the percentage (24.3\%) reported by the operator of Al Multaqa Landfill ( $p>0.05)$. The percentages reported for plastic by UNEP's International Environmental Technology Centre [22] for Accra, Ibadan, Dakar, Abidjan, and Lusaka were less than $10 \%$. This may be due to the prevalent reuse of plastic bottles and containers in Africa or to the restricted use of plastic bags [23]. The Environmental Protection Agency (EPA) of the United States showed that plastics comprised $12.8 \%$ of the total MSW generation in 2013 [15]. The high plastic component in Al Jabal Al Akhdar may be attributed 
to the activity of both local people and international tourists who tend to leave behind plastic packaging, especially plastic food containers, and plastic water and soft drink bottles in the area. There is no restriction on the use of plastic and plastic products in Oman, leading to the high quantities of plastic in solid waste.

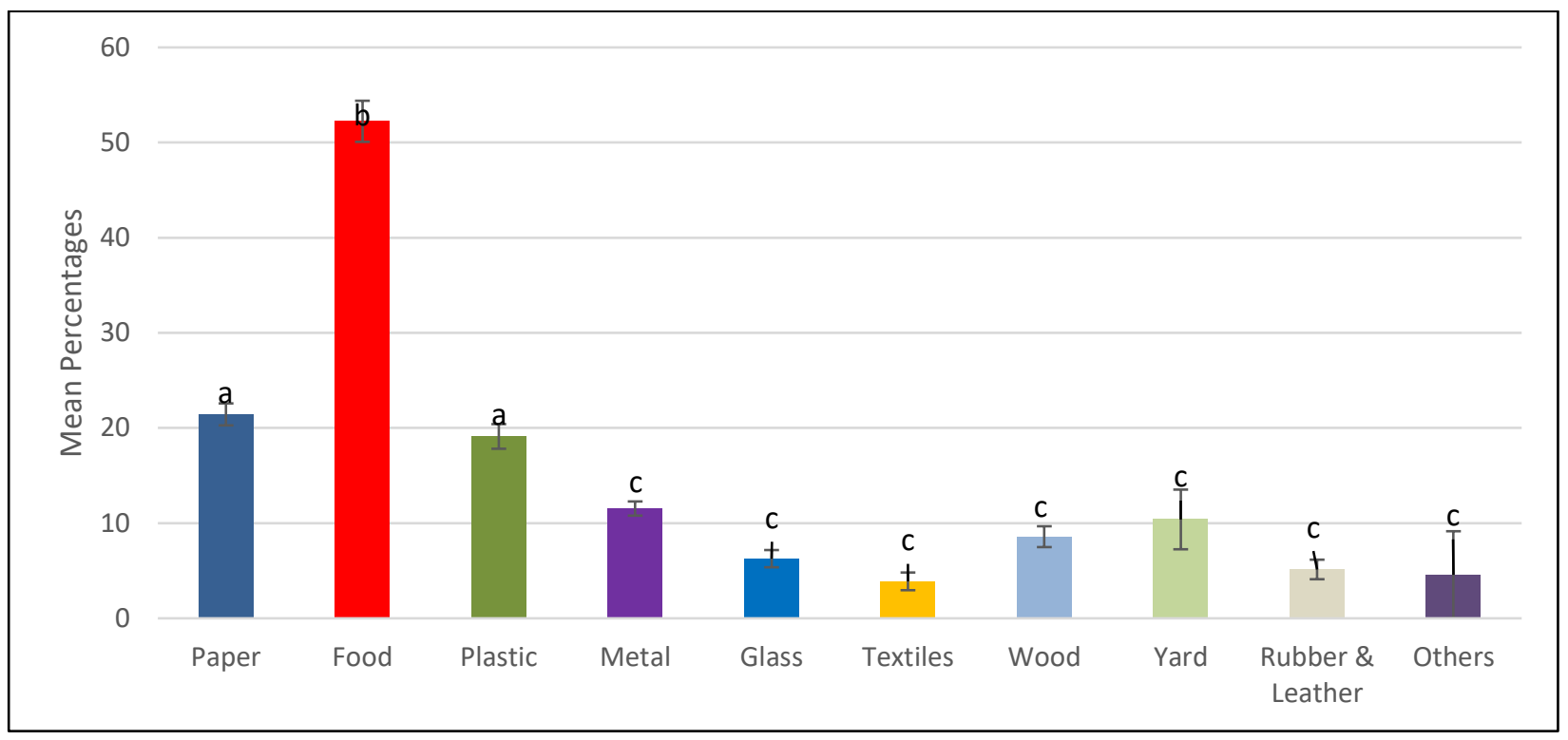

Figure 2b. Percentages of different categories of waste generated by Military. The bars labeled with the same letters are not significantly different from each other (Tukey test, $\mathrm{p}>0.05$ ).

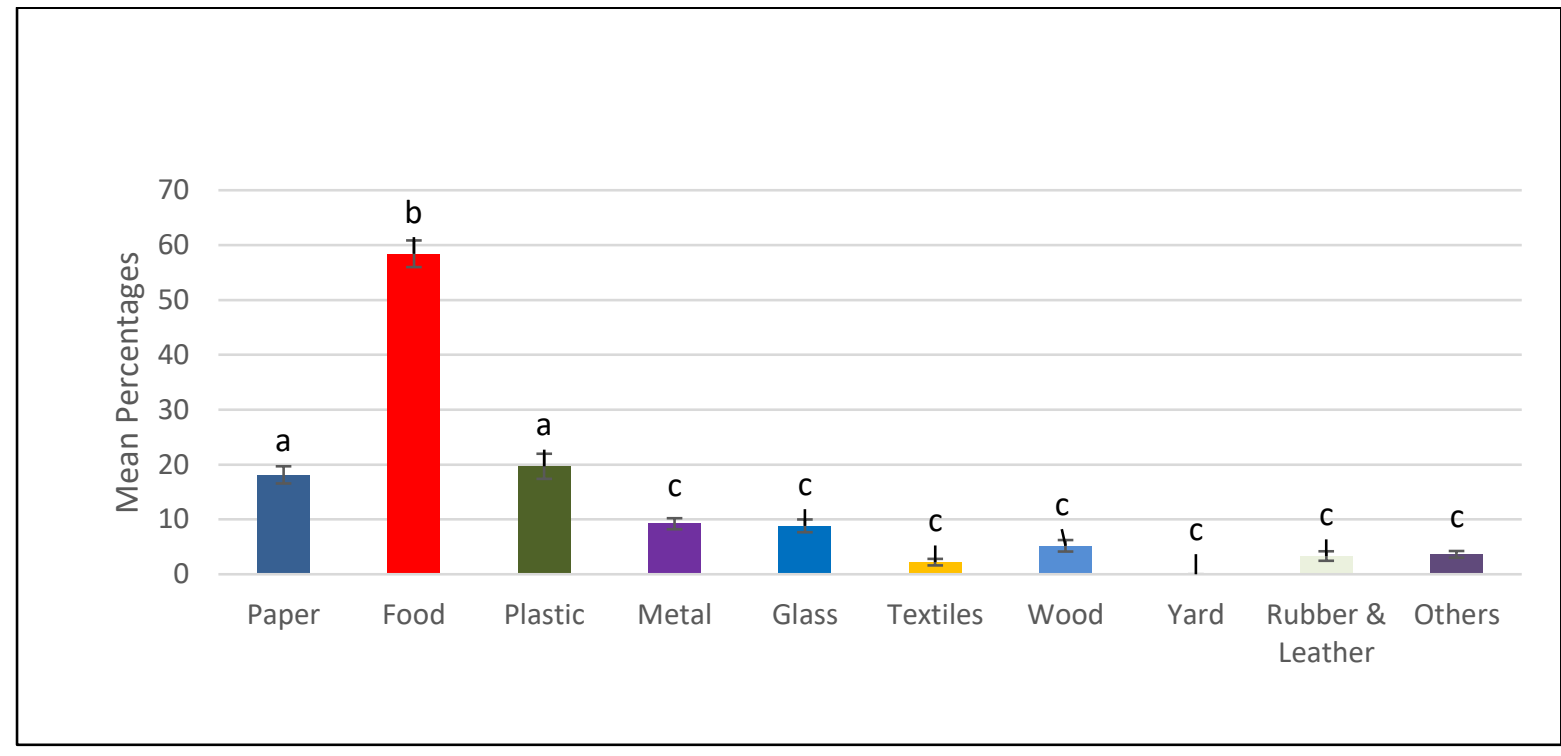

Figure 2c. Percentages of different categories of waste generated by Private Companies. The bars labeled with the same letters are not significantly different from each other (Tukey test, $p>0.05$ ).

Paper and cardboard waste contribute $17.9 \%$ of the total waste collected by the municipality in $\mathrm{Al} \mathrm{Jabal} \mathrm{Al}$ Akhdar. This was lower than that (28.8\%) reported by Palanivel and Sulaiman [18] and close to the $16.3 \%$ recorded by El Zawahry et al. [21]. The 21.4\% reported by the operator of Al Multaqa Landfill was not significantly different from that reported for Al Jabal Al Akhdar ( $\mathrm{p}>0.05)$. The data from USEPA showed that paper and cardboard accounted for $27.0 \%$ in 2013 [15].

The results of ANOVA showed that there were no significant differences $(p>0.05)$ among the percentage compositions of all categories of waste between the military and the private companies (Figure 3). For both these sources, the three main categories, plastic, food and paper represent $65-74 \%$ of the total waste. The major component is the food waste, comprising $37 \%$ of the military and $45 \%$ of the private companies' waste. Food waste is significantly higher in the military and the private companies when compared to the municipal waste $(\mathrm{p}<0.05)$. Military and private companies cater to a large number of personnel and waste large quantities of food. In these organizations, food is 
purchased in bulk and any food that is not used by the expiry date is disposed of. The quantity of food cooked is more than they actually consume, resulting in large quantities of waste food.

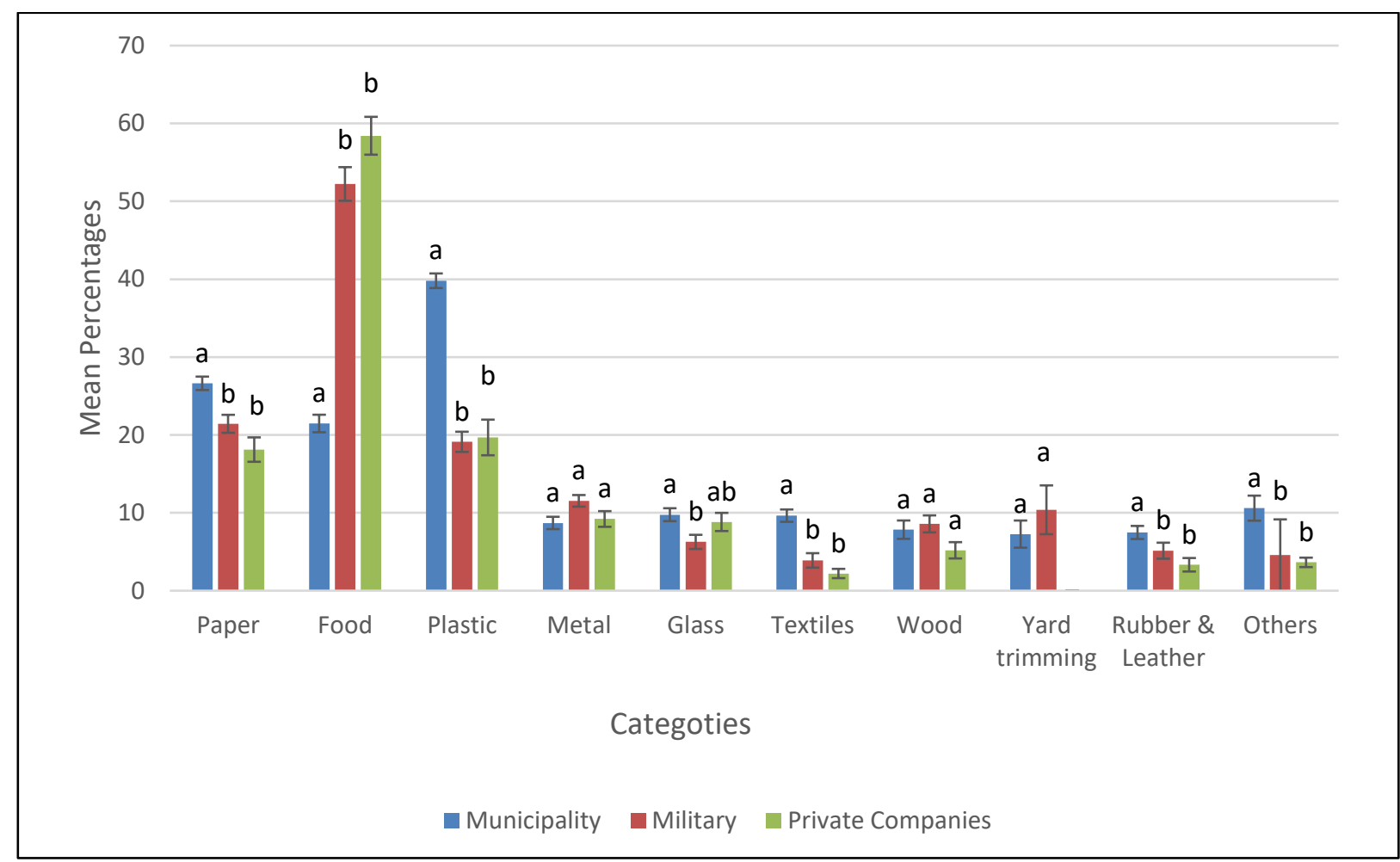

Figure 3. Comparison between each category coming from 3 different sources, with similar letters showing no significant differences $(p>0.05)$ and different letters indicating significant differences $(p<0.05)$.

The percentage composition of plastic and paper was significantly lower $(\mathrm{p}<0.05)$ for the military and private companies when compared to the municipality. Both military and companies use less diversity of materials as opposed to individual households. In households, consumer spending patterns and the phenomenon of "use and throw" result in the generation of more plastic and paper which are the main constituents of packaging materials. Paper and cardboard wastes are mostly generated by the commercial establishments in the area and are collected by the municipality. In contrast, the generation of paper and cardboard wastes discarded by the military and the private companies are relatively less.

There were two other categories of waste where the municipality was significantly different $(p<0.05)$ from the military and private companies. Textile wastes were higher in the municipality. Both military and commercial activities generally do not dispose of clothing and bedding materials whereas in households, the opposite is the norm. The military and private companies use these materials for a long period, and when discarded, they are usually taken by people with low income and eventually end up in the municipality waste.

The category designated as 'Others' was higher in the municipality waste, and it contained sanitary napkins and animal carcasses. This is also a reflection of the diversity of consumables used by families as opposed to personnel living in camps. Other items in this category are used tires and oil filters. Even the military and private companies change their old tires and oil at workshops outside their own camps; these also end up in the municipality waste.

Al Jabal Al Akhdar is a rural area in the Sultanate of Oman where solid waste is still managed by traditional systems of collection and disposal. It is useful therefore to make a comparison between this study and other studies from both developing and developed countries. Studies in San Quintin and Vicente Guerrero, northern Mexico [24], Darjeeling, India [4] and Muar, Malaysia [25], representing rural regions and developing countries, showed similarities to Al Jabal Al Akhdar in that food is one of the major categories in the household and municipal waste along with paper and plastic. In developed countries however, paper and paper board are the dominant waste, followed by food. For example, USEPA [15] estimated that paper and paperboard represent $28.0 \%$ followed by food waste at $14.5 \%$. The United States (U.S) produces and uses a third of the world's paper, and an average U.S citizen uses more than $300 \mathrm{~kg}$ of paper per year. In the United States, the use of paper is not controlled by legislation as it is considered to be biodegradable. 


\section{ABDULLAH I. AL-MAHROUQI and REGINALD VICTOR}

\section{Conclusion}

The ultimate aim of this study was to produce an integrated waste management plan for the entire $\mathrm{Al} \mathrm{Jabal} \mathrm{Al}$ Akhdar area taking into account the anticipated urban expansion, tourism and development. Data on waste composition and characteristics are essential in order to properly plan and design waste management systems. This study indicates that the municipality should implement a system for the collection and recycling of plastic waste. Most mountain areas with high impact tourism have put a ban on the use of plastic bags in all commercial establishments and this strategy should be considered seriously for Al Jabal Al Akhdar. The military and private companies should reduce the quantities of food waste by improved planning and management of the catering services. Organic waste should be composted for use in agriculture. The data presented in this study provide a benchmark for future studies in $\mathrm{Al}$ Jabal $\mathrm{Al}$ Akhdar.

\section{Acknowledgements}

This work was supported by a scholarship awarded by Sultan Qaboos University to one of us (A.I. Al- Mahrouqi) for the doctoral research. We thank Al Jabal Al Akhdar Municipality for their support during waste segregation and for giving us permission to work at their dumpsite. The authors also thank Mr. Peter Sinclair Reid for his help in reviewing this article.

\section{References}

1. Ogwueleka, T.C. Municipal solid waste characteristics and management in Nigeria. Iran Journal of Environment, Health Sciences and Engineering, 2009, 6(3), 173-180.

2. Senior, E. Microbiology of landfill sites. CRC Press, Boca Raton, Florida, 1990.

3. Yusof, M., Othman, F., Normala, H. and Ali, N. The role of socio-economic and cultural factors in municipal solid waste generation: A case study in Taman Perling, Johor Bahru, Malaysia Journal of Technology, 2002, 37(F), 5564.

4. Limbu, D. Solid waste management in the town of Darjeeling: Environmental concern. International Journal of Humanities and Social Science Research, 2014, 3, 26-34.

5. Sabejeje, A.J., Oketayo, O.O., Bello, I.J. and Sabejeje, T.A. Elemental analysis of leachates from open-dump-solid wastes in Ondo State, Nigeria: Implication on underground water and surface water safety. American Journal of Research Communication, 2014, 2(10), 287-296.

6. Hamdi, H., Jedidi, N., Ayari, F. and Ghrabi, A. Valuation of municipal solid waste compost of Tunis (Tunisia) Agronomic aspect. Proceedings of the 14th Annual Conference of the Japan Society of Waste Management Experts, 2003, 3, 62- 64.

7. Glennie, K.W. The Geology of Oman Mountains. An outline of their origin. Scientific Press Ltd., U.K., 2005.

8. Hanna, S.S. Field guide to the geology of Oman volume 1, Western Hajar Mountain and Musandam. The Historical Association of Oman, Sultanate of Oman, 1995.

9. Ministry of Transportation and Communication. Annual temperature degree and rainfall in Al Jabal Al Akhdar, General Directorate of Meteorology and Air Navigation (DGMAN). Muscat, Sultanate of Oman, 2009.

10. Ministry of Tourism. Annual report for tourism in Al Jabal Al Akhdar. Muscat, Sultanate of Oman, 2014.

11. Ministry of National Economy. Oman General Census of Population, Housing, and Establishments 2010. Muscat, Sultanate of Oman, 2011.

12. Klee, A.J. Design \& management for resource recovery volume 3: quantitative decision making. Ann Arbor Science, Ann Arbor, Mich, 1980.

13. Monney, I., Tiimub, B.M. and Bagah, H.C. Characteristics and management of household solid waste in urban areas in Ghana: the case of WA. Civil and Environmental Research, 2013, 3(9), 10-21.

14. Sharholy, M., Ahmed, K., Vaishya, R.C. and Gupta, R.D. Municipal solid waste characteristics and management in Allahabad, India. Waste Management, 2007, 27, 490-496.

15. USEPA (USA Environmental Protection Agency). Municipal solid waste in the United States: Facts and figures for 2011. Washington, Dc, 2013. <https: // epa.gov/wastes/nonhaz/municipal> (accessed 20.02.2016).

16. Osei-Mensah, P., Adjaottor, A.A. and Owusu-Boateng, G. Characterization of solid waste on the AtwimaNwabiagya District of the Ashanti region, Kumaisi-Ghana. International Journal of Waste Management. Technology, 2014, 2(1), 1-14.

17. Muscat Municipality. Monthly operation report for Al Amerat (Al Multaqa) Solid Waste Landfill. Muscat, Sultanate of Oman, 2013.

18. Palanivel, T.M. and Sulaiman, H. Generation and composition of municipal solid waste (MSW). Asia-Pacific Chemical, Biological and Environmental Engineering Procedia, 2014, 10, 96-102.

19. Abd-Alqader, A. and Hamad, J. Municipal solid waste determination supporting the integrated solid waste management in Gaza strip. International Journal of Science and Development, 2012, 3(2), 172-176.

20. Gidarakos. E., Havas, G. and Ntzamilis, P. Municipal solid waste composition determination supporting the integrated solid waste management system in the island of Crete. Waste Management, 2006, 26, 668-679. 
21. El-Zawahry, A., Shahalam, A., Taha, R., and Al-Busaidi, A. An Assessment of Solid Waste and Landfills in Muscat Area, Oman. Sultan Qaboous University Journal of Science and Technology, 2001, 6, 1-11.

22. UNEP (United Nations Environmental Program). Municipal Solid Waste Composition Analysis Study: Juba, South Sudan, 2013 <http:// unep.org/ South Sudan > (Accessed on: 23/12/2015).

23. Bashir, N. Plastic problem in Africa. Japan Journal of Veterinary Research, 2013, 61 (Supplement), S1-S11.

24. Taboada-González, P., Armijo-de-Vega, C., Aguilar-Virgen, Q. and Ojeda-Benítez, S. Household solid waste characteristics and management in rural communities. Open Waste Management Journal, 2010, 3, 167-173.

25. Kalanatarifard, A. and Yang, G. Identification of the municipal solid waste characteristics and potential of plastic recovery at Bakri landfill, Muar, Malaysia. Malaysian Journal of Sustainable Development, 2012, 5(7), 11-17.

Received 16 June 2016

Accepted 12 December 2016 